\title{
Reinventing the Portuguese knitwear industry: the case of Pedrosa \& Rodrigues private label management model
}

DOI: $10.35530 / I T .072 .05 .202035$

\section{ABSTRACT - REZUMAT \\ Reinventing the Portuguese knitwear industry: the case of Pedrosa \& Rodrigues private label management model}

During the first decade of this century, the Portuguese knitwear industry, and textile cluster, were strongly affected by globalisation and seemed destined to decline. The Portuguese knitwear industry developed for decades a business model based on price as the main competitive factor, and that model was no longer able to support competitiveness against low wages countries. Portuguese knitwear industry made a dramatic change towards a competition based on value to the client. The companies adopted as primary differentiation drives technological innovation, design, fashion, and services customer-oriented, together with more presence on international fairs and exhibitions. The new strategy resulted in the significant growth of exports that reached 40\% from 2009 to 2018. The restructuring of the cluster, however, changed it significantly, and the number of companies was reduced by almost $50 \%$. The competitive change made the entire Portuguese textile cluster an international case study where the modern concept of private label business model is central.

The business model of private label adopted by the most competitive knitwear companies considered a full package of services to international clients. It integrated the collection's design, raw materials development, superior finishing, careful and cost-effective confection and sophisticated logistics. Pedrosa \& Rodrigues, SA. is a midcap company from Barcelos County, North of Portugal, and is a highly successful example of the new competitive paradigms. This new model is now leading the Portuguese knitwear industry to a higher level in the value chain and gives it a strong reputation worldwide.

Keywords: private label, design service oriented, textile industries new paradigms, organisational innovation, sustainable value chain

Reinventarea industriei portugheze de tricotaje: cazul modelului de management al etichetei private Pedrosa \& Rodrigues

În primul deceniu al acestui secol, industria portugheză de tricotaje și clusterul textil au fost puternic afectate de globalizare și păreau să intre într-un declin. Industria portugheză de tricotaje a dezvoltat timp de decenii un model de afaceri bazat pe preț ca principal factor competitiv, iar acel model nu mai era capabil să susțină competitivitatea în țările cu salarii mici. Industria portugheză de tricotaje a făcut o schimbare dramatică către o concurență bazată pe valoare adăugată pentru client. Companiile au adoptat ca motor de diferențiere primară inovația tehnologică, designul, moda și serviciile orientate către client, împreună cu o mai mare prezență la târgurile și expozițiile internaționale. Noua strategie a avut ca rezultat o creștere semnificativă a exporturilor, care a atins 40\% în perioada 2009-2018. Cu toate acestea, restructurarea clusterului a schimbat acest lucru în mod semnificativ, iar numărul companiilor a fost redus cu aproximativ $50 \%$. Schimbarea concurențială a făcut ca întregul cluster textil portughez să devină un studiu de caz internațional, în care conceptul modern al modelului de afaceri cu etichetă privată este central.

Modelul de afaceri cu etichetă privată adoptat de cele mai competitive companii de tricotaje a luat în considerare un pachet complet de servicii pentru clienții internaționali. A integrat designul colecției, dezvoltarea materiilor prime, finisaje superioare, produse atent create și rentabile, precum și logistică sofisticată. Pedrosa \& Rodrigues SA este o întreprindere mijlocie din regiunea Barcelos, din nordul Portugaliei și este un exemplu de mare succes al noilor paradigme competitive. Acest nou model conduce acum industria portugheză de tricotaje la un nivel mai înalt în lanțul valoric și îi conferă o reputație puternică în întreaga lume.

Cuvinte-cheie: etichetă privată, orientare către design, noi paradigme ale industriei textile, inovație organizațională, lanț valoric durabil

\section{INTRODUCTION}

Globalisation has altered competitiveness dynamics [1]. In the last decades, the high degree of openness of the nations' economy, enhanced by globalisation, has transformed the world [2-4] causing nations, economic sectors and even individuals to adapt to an environment characterised by increased competition, speed and frequency of changes [5].

The fashion market also became synonymous with rapid changes and, as a result, commercial success or failure in the markets depends on the flexibility and responsiveness of organisations [6]. According to Henderson [7], the strategy contributes to a deliberate 
search for an action plan that will develop a competitive advantage for the business. The essence of the strategy is to choose a unique positioning and a differentiated value chain [8]. On the other hand, Rowley, Bareghehe and Sambrook [9] point out that there is widespread recognition of the growing importance of innovation for organisations and economies. In this way, companies' survival depends on their ability to implement R\&D strategies and acquire advanced technological knowledge to generate ideas about new products or improve current ones, remaining ahead of their competitors [10].

As Cheng et al. [11] pointed out, the competitiveness between national brands and private label brands has been a fundamental research area in the last decade [1]. According to Hsiao et al. [12], some studies have focused on consumer attitudes towards private label $(\mathrm{PL})$ brands. Other relevant studies examine the relationship between quality and price.

This research work aims to identify aspects of competitiveness and strategy adopted by companies that adopt the private label model to face global competitiveness in the textile and clothing industry. The case study method allowed an in-depth analysis of how companies implemented the private label model. Pedrosa \& Rodrigues over the last decade has successfully implemented the private label model, and its' study can contribute to the understanding of the requirements faced by companies that wish to adopt this model.

\section{COMPETITIVENESS IN THE NEW MARKET CONDITIONS}

\section{Competitiveness and strategy}

Competitiveness is a concept that implies different meanings for companies and a country's economy [13]. In a general perspective, according to Mariotto [14] and Teixeira [5], the term competitiveness is applied to both nations and companies. The concept refers to the ability of an organisation or nation to be successful in the market despite national and world competition.

For Porter [15], the strategy consists of creating a unique and valuable position, involving a different set of activities. On the other hand, a strategy is the set of decisions and actions of the company that, consistently, seek to provide customers with more value than that offered by the competition. The strategy is a deliberate search for an action plan that will develop a competitive advantage for the business [7]. Thus, the essence of the strategy is to choose a unique positioning and a differentiated value chain [8]. For Miranda [16], from goals to policies, among other configurations, the strategy is described as a process of maturation and natural evolution of the complex activity of business management conditioned by technological, economic, social and environmental developments.

Teece, Pisano and Shuen [17] substantiate, on the other hand, that strategic management consists of the way companies achieve and sustain a competitive advantage. Porter and Kramer [8] emphasise that the strategy theory holds that, in order to be successful, a company must create a distinctive value proposition that meets the needs of a set of customers. The company obtains a competitive advantage through the way it sets up the value chain or the set of activities involved in the creation, production, sale, delivery and support of its products or services.

For a company, a competitive strategy is to be different. It means intentionally choosing a different set of activities to offer a unique combination of value [15; 18]. The objective is to find a way to position itself in the industry, in order to benefit from the competitive forces model: (1) rivalry between competing companies; (2) suppliers' bargaining power; (3) customers' bargaining power; (4) threat of new entries; and (5) threat of substitute products [19]. According to this model, customers, suppliers, substitutes and potential entries, as well as competitors, exert pressure on the company, which will be greater or lesser, according to each case [14]. The strategic decision process is considered an essential part of the process in which organisations adapt to the contextual environment. Porter [15] also presents a typology of strategies that the company can use to face the five forces of competition successfully [14]. They are called generic strategies because they can be adopted by any business unit [20]. The adoption of any of the three strategies (differentiation, cost and specialisation) would imply full support from the organisation concerning the chosen strategy, so this would imply a non-adoption of more than one strategy at the same time by the organisation [5].

However, as Moraes and Zilber [20] point out, several authors developed concepts that contradict Porter's model, generating so-called hybrid strategies that propose that companies can simultaneously and profitably adopt cost leadership and differentiation.

\section{Competitiveness of the textile and clothing industry}

Nowadays, companies face new challenges, and more aggressive competition prevails, with more complex products and more demanding consumers [21].

The textile industry and its' context struggle to keep developing the process of modernisation, driven by the emergence of entirely new or more sophisticated textile technology, together with the growing competition for markets and products. The process was developed in the industrialised countries and afterwards expanded to recently industrialised and developing countries, many of which use the latest textile technologies as a way to guarantee a competitive position, especially in export markets [22]. According to Lee and Östberg [23] due to its labour-intensive nature, this industry generally occurs in economies that are in the early stage of development. However, as the economy develops to become highly industrialised, wages increase, and the economy loses its price competitiveness. 
Currently, in Europe, the textile and clothing sector continues to play a significant role in the European economy. Its eventual decline could have a significant impact on the EU economy [24] since 185,000 companies, mostly SMEs, remain in operation, employing 1.7 million workers $(6 \%$ of employment in the EU), and generating a turnover of 166 billion euros ( $3 \%$ of the EU added value) widely distributed across the EU. However, a substantial part of textiles and clothing consumed in the EU is produced in other parts of the world, mainly Asia, taking advantage of the lower wage cost. The disadvantages of this model include long-distance supply chains, poor working conditions and high environmental costs [25].

The Portuguese textile and clothing industry is one of the most important manufacturing activities in the national economy. It represents about $3 \%$ of GDP, $10 \%$ of merchandise exports, $20 \%$ of employment, $9 \%$ of production and $11 \%$ of the GVA of the national manufacturing industry. In absolute numbers, its expression is even more significant: 7.6 billion in turnover, 7.5 billion in production, 5.3 billion in exports and 134 thousand direct jobs. It outranks more than five times the cork sector and more than 2.5 times the footwear industry [26]. The sector is more important from a regional point of view since the sector is strongly concentrated in the North Literal part of the country, with particular importance in areas, Braga and Porto that represent $57 \%$ and $24 \%$ of the total sector volume of trade (figure 1).

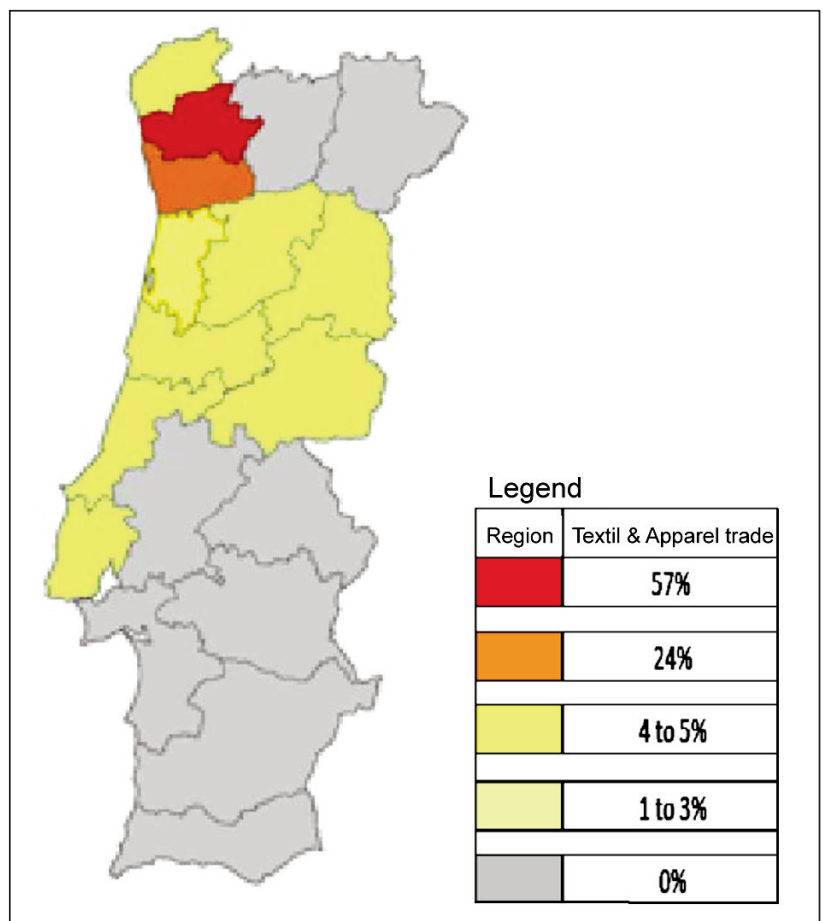

Fig. 1. Textile and clothing trade regional distribution in Portugal

The demand for the textile and clothing industry is highly dependent on the disposable income and the general economic well-being of the regions. The last decade the sector has benefited from an increasing number of consumers who have chosen to buy more garments at lower prices, generating revenue and profit in the sector [27].

Taking into account the Portuguese context it appears that textile companies face strong competitiveness in two ways. On the one hand, the presence of large international textile and clothing companies that mainly adopt a cost-leading strategy and, on the other hand, several brands of already established manufacturers that transfer a large part of their manufacture to low-income countries. However, the Portuguese textile companies that survive are those that continue with their production in the domestic market [10].

\section{The new fashion design paradigm and the private label model}

Fashion design aims to develop clothing and accessories respecting cultural, technical, and market trends. Fashion design is a means of communication, whether intentional or not, and Kratz [28] supports that fashion is an intangible and symbolic product. The analysis of this immaterial work produced by the designer cannot lose sight of what is inserted in the industrial process of fashion and clothing.

Preiholt [29] refers that in the past, fashion was connected with the leading fashion capitals, such as Paris, London, Milan and New York, and was primarily influenced by their intercultural environment. However, nowadays, it becomes more challenging to identify the sources of international fashion, in terms of global production and consumption. One of the characteristics of contemporary fashion is that it went from being a collective choice to becoming an individual choice, consumers mixing more and more styles, instead of adopting single brands.

The use of social networks contributed to change the way fashion is presented, disseminated and used. Consumers started to share information and create content. This new behaviour led designers and brands to consider consumers' opinions, in order to produce articles according to their needs and preferred trends, but also to listen to their opinion about competitors' products [12].

Rossi and Harger [30] consider it essential that companies follow market trends and innovations that, in the case of fashion, consider fabrics, colours, prints, cuts, shapes, among other elements.

Lima [31] states that the introduction of internal or external skills in terms of the design means a presentation of increasingly bold proposals with customers, with whom a relationship is established that provides an increase in the number of orders. Many companies, regardless of their size, already have internal creative departments, with textile and fashion designers, who develop solutions for their brands or third parties. Currently, companies, even those that work only for third party brands or in PL, offer a fullservice package, consisting of the collection design, material development, industrial production and distribution logistics [32].

ATP [26] also highlights the importance of possessing skills in the field of design. Those competencies are 
essential to fully acquire the skills that the major brands transfer to the most sophisticated and qualified suppliers, retaining valuable customers and attracting new ones, in increasingly sophisticated markets and niches. Margins that are more significant reward the permanent removal from the competition based on price and the search for competition through differentiation.

In the future, it is expected that ITV's business in the PL model will be to maintain and evolve by integrating more benefit into the final product. For this, it will be necessary to invest in strategies for innovation in processes and organisation, in increasing cooperation with customers and suppliers, in increasing skills that allow improving the conditions of supply with advantages for the markets [26]. Companies must adopt a new position in these businesses, working as if they are the "innovation department" of their clients' brands and thus obtaining competitiveness through specialisation and innovation.

\section{METHODOLOGY}

Authors such as Sauders et al. [33] postulate an investigation process that allows the understanding of the object of study by successive approximations that was adopted. Given the nature of the study to be carried out and its objectives, it resulted the following steps: i) definition of the research theme; ii) critical review of the literature and existing information on the topic, in order to define the theoretical framework; iii) selection of companies, the object for study, that obeys a pre-defined set of criteria: location, dimension, specialisation, degree of internationalisation and intensity in the use of design as a critical factor of competitiveness and differentiating the respective value proposal; iv) data collection of the companies under study; v) data analysis and interpretation.

The case study was defined as the primary method in the work, as this is empirical research [34], that begins with exploratory goals and evolves to achieve an in-depth understanding of the evolution of the implementation of a concrete management model and in a real context, according to the guidelines proposed by Robson [35] and Yin [36]. There are several types of case study, and in the present research, the one we used is the "emancipatory" [35].

The case study of Pedrosa \& Rodrigues will be combined and compared with others carried out on the same collective object of study [37], which is the circular knitting industry in the municipality of Barcelos. The case study considered three levels of information: the company's economic and financial indicators from the last ten years, the consultation with secondary sources, consisting of interviews and published reports about the company, and semi-structured interviews with its Directors, Casimiro Rodrigues, the founder of Pedrosa \& Rodrigues, and Miguel Pedrosa Rodrigues, member of the company management. The information collected, processed and analysed allowed to achieve the objective of indepth understanding of the implementation process of the strategic private label model in the knitwear industry and the drawing of conclusions regarding the possible adoption of this model by companies in the same or other industrial branches.

\section{RESULTS}

Pedrosa \& Rodrigues is a textile company, semi-vertical, from the circular knitting subsector, located in the municipality of Barcelos, specialising in women's fashion, working practically exclusively for the foreign market, under private label regime. In 2017 this company had a turnover of 15,6 million euros and employed 109 direct workers.

On its website (www.pedrosa-rodrigues.pt), the company presents itself as an industrial company specialised in high-end clothing, that offers its' clients design and clothing items development according to the customer's specifications. The company follows a 21 steps protocol that goes from the design sketch, presented by the client or by its' design department, and ends with sending the invoice to the customer. The focus of this protocol is on high efficiency, fluidity and transparency in the process, in order to offer the client an excellency level service and reliability. The company differentiates itself from the competition by the solidity of these arguments put into practice. Pedrosa \& Rodrigues (P\&R) was founded in 1982 by the couple Sabina Rodrigues and Casimiro Rodrigues, having taken off in the garage of Sabina's parents. Casimiro was involved in car repair, while his wife already worked in the clothing sector, in the cutting department. Both felt dissatisfied and unused in their abilities and desired higher challenges. The first years were hard, with the founders doing practically everything there was to do, working in a "multitask" and "nonstop" regime from Tuesday to Friday. The effort paid off, and gradually, the company abandoned the collaboration with national companies to produce and export directly to international clients. Casimiro Rodrigues stated that the strategic change aimed to obtain a more significant margin and to support the company expansion since it was necessary to offer higher benefit to conquer clients that are more demanding. The strategic option was to follow the evolution of the Italian market, transferring the offer of minutes to the offer of value. The founder of P\&R also stressed as very important the territorial context in which the company operates, as in Barcelos region, all companies had exports as their goal, it did not matter how small they were.

Miguel Pedrosa Rodrigues, second-generation company manager, and a trained architect reinforce this last competitive factor and consider that to operate in a 'cluster' brings the company a significant competitive advantage. The proximity among the agents in the sector allows them to know the professionals and companies that compose it, along with their agility, competencies, and production quality. The central value within this cluster is to add more value to customers and satisfy orders with the minimum organisational dimension possible. The cluster became an 
excellent hub of knowledge and credibility when investing in long-term strategies requiring solid relationships with workers, suppliers and customers.

Miguel Pedrosa Rodrigues vision follows the company's founders market perception concerning the values and principles that built and define the company's culture: focus on the solution to the customer, focus on the added value as a market differentiator, relational stability with the company's human capital and all other stakeholders, including suppliers and customers. He considers his vision is fully supported by the fact that the company has an enormous capacity for customer loyalty since after working two collections with the company, they tend to keep it as their supplier. This loyalty affects mainly high-end clients, brands like Helmut Lang, Zegna or Diane von Furstenberg, with whom the company may already be negotiating only manual operations. In the present, the company still works with a floating fringe of other customers of the superior medium segment, to obtain production scale, and customer requirements define the standard of quality. The mixture between superior medium and high-end clients is an asset, as the variety generates resilience and requires the company to implement and develop very robust processes in order to keep flexible, and highly efficient. The complex and sophisticated private label business model developed Pedrosa \& Rodrigues has another critical competency, the endogenous existence of skills of design and fashion knowledge, central to meet the demands of international customers. This strategic orientation determined a specific organisation that integrates the Design Department in the Commercial Department, and the designers are requested to work always assuming the clients' perspectives and visions, as an extension of the client's Design Department. The Design Department is also expected to contribute to bringing to the company new businesses. Pedrosa \& Rodrigues management assumes that the company is a production, industrial one, focused on the private label model. This model, as developed by $P \& R$, is an evolutionary process that requires permanent investment and organisational fully committed resources.

The present market challenges, the emergence of new generations of consumers with diverse values and purchasing behaviours, some even disruptive, based on sustainability, ecology and social responsibility, as well as new information and sales channels, of a digital nature, has led the company to invest in market knowledge and consumer behaviour. The investment in social networks, especially on Instagram, and industry 4.0, with a logic of collecting and processing permanent information about the product and the customer, is crucial to maintain continuous improvement and a superior degree of excellence in the provision of service to the clients. The private label model suits to a new client that is not interested in technical issues, equipment or the production process, as was the case with previous generations. Today, the focus is on the profit margins the client can get from the order he places, considering that the supply chain is reliable and the quality is achieved, at the right time and the right price.

The price kept its central importance in the value chain. However, it cannot be critical to the business model that was developed by P\&R. The company faces the challenge of increase the number of customers who do not consider prices critical. Those targeted clients value above all the service package and other variables such as high-value finishing. Because of this strategy, the prices went up systematically since 2011, but the sales kept growing until 2017 at a double-digit pace, reaching almost 16 million Euros. In 2018, turnover fell slightly, due to "Brexit" and Turkish competition, with the aggressive currency devaluation and the country's political stabilisation. The present and future challenges are to invest in continuous organisational, product development, and manufacture improvement. The goal is to keep being better, more efficient, to do more with less, to eliminate waste and increase efficiency, in a continuous process. It is the strategy to maintain competitively over time. Other challenges for the future are the automation of clothing making, and the consolidation of industry 4.0 technologies and processes, in which they already operate. It is also expected that the industry will have growing difficulty in finding available workers and it will be necessary to socially value the work of the seamstress, situated between handicrafts, fundamental in luxury and high-end products. The company also expects that to keep competitive will have to relocate orders, especially those from clients more sensitive to price. This way it will be possible to offer clients a mix of service and price that holds them holistically, keeping the decision centre in the company, as well as the benefit generated.

The managers outlined another angle of their vision: the company is an industrial studio, dedicated to the medium, high and very high segments, which requires flexibility and very short lead-time. The customers already classify the Portuguese knitwear and textile industries as the "fastest lead time supplier". P\&R also works with small quantities, and customisation, which requires a great capacity for process management, including what today is called the industrialisation of customisation. However, this full range of service is available only for the high-end customer, who values it.

The future development of the private label model at P\&R unfolds in a vision of organic growth, stability and sustainability. The company's managers defined a strategy that maintains the organisation as a family business, small and highly sophisticated, agile, flexible and specialised. They intend to gain scale through cooperation with other Portuguese companies in the cluster and keep the strategic focus on profitability overgrowth. The company's performance from 2007 to 2018 (tables 1) prove the efficiency of the private label model at P\&R, on virtually all performance indicators, from sales volumes to workforce, net results and cost reduction by net results. 


\begin{tabular}{|l|c|c|c|c|c|c|c|c|c|}
\hline \multicolumn{10}{|c|}{ "PEDROSA \& RODRIGUES"/MAIN INDICATORS } \\
\hline \multicolumn{1}{|c|}{ Indicators } & $\mathbf{2 0 0 7}$ & $\mathbf{2 0 0 8}$ & $\mathbf{2 0 0 9}$ & $\mathbf{2 0 1 0}$ & $\mathbf{2 0 1 1}$ & $\mathbf{2 0 1 2}$ & $\mathbf{2 0 1 4}$ & $\mathbf{2 0 1 6}$ & $\mathbf{2 0 1 8}$ \\
\hline Turnover (1000 euros) & 7.378 & 7.714 & 6.312 & 8.153 & 8.452 & 6.385 & 9.483 & 14.114 & 13.022 \\
\hline Direct Jobs & 89 & 88 & 82 & 83 & 93 & 77 & 79 & 99 & 109 \\
\hline Exports & 7.230 & 7.508 & 6.276 & 8.137 & 8.353 & 6.296 & 9.173 & 13.605 & 12.945 \\
\hline \% on exports & 98 & 97 & 99 & 99 & 99 & 99 & 97 & 96 & 99 \\
\hline $\begin{array}{l}\text { Eat - earnings after taxes } \\
\text { (1000 euros) }\end{array}$ & 157 & 129 & 111 & 266 & 381 & 103 & 823 & 1.311 & TBC \\
\hline Ebita over sellings (\%) & 7 & 6 & 7 & 8 & 9 & 6 & 13 & 13 & 11 \\
\hline Medium price/1 piece (euros) & 7.38 & 7.72 & 8.4 & 9.66 & 11.24 & 11.01 & 10.43 & 13.5 & 13.62 \\
\hline Investment fbcf (1000 euros) & N.A. & 491 & 443 & 356 & 48 & 8 & 292 & 544 & TBC \\
\hline $\begin{array}{l}\text { Investment on design and } \\
\text { sustainability }\end{array}$ & - & - & - & - & - & - & 40 & 33 & 62 \\
\hline
\end{tabular}

Note: TBC - to be confirmed, as final numbers are not yet concluded for 2018; N.A. - not available.

\section{CONCLUSIONS}

The Portuguese Textile and Clothing Industry has undergone a profound paradigm shift in the last twenty years. Due to a set of global competitive shocks, the entire sector went through a continuous restructuring path. It reinvented itself by adopting new critical competitiveness factors, achieving, this way, a degree of success that is internationally recognised, to the point that the Portuguese textile and clothing sector is considered a "case study" on a global scale, which many want to emulate as a model.

This paradigm shift can be summed up in three fundamental considerations:

- the sector was no longer able to compete for price (aggressive Asian competition based on the low cost of labour) and started to compete for value (which differentiates companies and their products by design, technological innovation and service intensity, which today characterise the sophisticated private label models, which offer the market a "full package service");

- the sector is no longer a passive order taker but an active seller of solutions, oriented to the interests of the client, in which the "full package service", which characterises the Portuguese private label model is a crucial element in the business model;

- finally, the sector ceased to present itself as an erratic and straying sum of individual companies' initiatives, more or less voluntary, to have a collective strategy, capable of bringing together the different actors, including the scientific and technological system, the associations and the State itself (public policies and community funds), in order to better allocate scarce resources to perfectly defined and quantifiable goals.

Pedrosa \& Rodrigues, a small/medium size company in the circular knitwear subsector, specialised in women's clothing in the medium, high and premium ranges, located in Gilmonde, Barcelos, is one of the best examples we can find in this domain.
In a constant process of continuous and sustainable incremental improvement, $P \& R$ built its private label business model that is, working for third-party brands always refusing to implement a brand strategy.

The private label model works the development of a "full-service package", which includes the offer of design services, creation and development of collections, materials and processes innovation, among other values to the client.

The focus on efficiency, adequate quality and customer service, which has become a real obsession, shared by all the company's professionals, positively differentiates Pedrosa \& Rodrigues from its competition. Completely integrated into the new private label business model of the Portuguese knitwear industry, $P \& R$ can assert itself as one of this model best performer, contributing permanently to improve it.

The role of the Design Department, in this specific private label model developed by Pedrosa \& Rodrigues, should be highlighted as it works under the supervision of the Commercial Department, permanently focused on interpreting the needs of the buyers. The design assumes, in this context, the organisational goal of understanding the client needs and requirements and deliver him this knowledge in the form of fashion or clothing items and collections. The service package of the model considers a logic of design oriented to business, in which creativity can have broadband, from the consolidation of the client's superior specifications to the freedom of innovative and disruptive proposals. The communication methods and tools that the company developed maximise production efficiency and promote a better interaction with its customers, and the market in general, without which it would not be possible to know and meet their needs and offer efficient service.

P\&R business model analysis brings an example for other companies in the sector as well as for other sectors of activity specialised in B2B businesses. The present competition pressure places the competitive 
advantages in the domain of value generation supported by knowledge centres internal to the organisation that allow differentiating the offer by creating value for the customer, significantly reducing the weight of the competition on price.

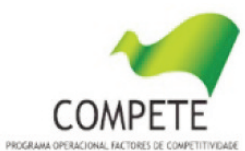

\section{ACKNOWLEDGEMENTS}

The authors gratefully acknowledge the Project UID/CTM/00264/2019 of 2C2T - Centro de Ciência e Tecnologia Têxtil, funded by National Founds through FCT/MCTES.

REFERENCES

[1] Girard, T., et al., Consumer-based brand equity of a private-label brand: Measuring and examining determinants, In: Journal of Marketing Theory and Practice, 2017, 25, 1, 39-56

[2] Wiersema, M.F., Bowen, H.P., Corporate diversification: the impact of foreign competition, industry globalization, and product diversification, In: Strategic Management Journal, 2008, 29, 115-132

[3] Carvalho, L., Serio, L., Vasconcellos, M., Competitividade das nações: análise da métrica utilizada pelo World Economic Forum, In: Revista de Administração de Empresas., 2012, 52, 4, 421-434

[4] Bang, K., Markeset, T., Impact of Globalization on Model of Competition and Companies' Competitive Situation, In: International Conference on Advances in Production Management Systems (APMS), 2017, 276-286

[5] Teixeira, F., A influência das especificidades culturais locais na competitividade de clusters: estudo de caso do cluster da malacocultura da região da Grande Florianópolis, Tese de Doutoramento. Escola de Engenharia, Universidade do Minho, 2016

[6] Christopher, M., Lowson, R., Peck, H., Creating agile supply chains in the fashion industry, In: International Journal of Retail and Distribution Management, 2004, 32, 8, 367-376

[7] Henderson, B., The Origin of Strategy, In: Harvard Business Review, 1989, November-December

[8] Porter, M., Kramer, M., Creating Shared Value: How to reinvent capitalism - and unleash a wave of innovation and growth, In: Harvard Business Review, 2011, January-February

[9] Rowley, J., Baregheh, A., Sambrook, S., Towards an innovation-type mapping tool, In: Management Decision, 2011, 49, 1, 73-86

[10] Rezazadeh, A., Carvallho, A., Towards a surviivall capabiilliitiies framework: Lessons from the Portuguese Textiille and Clothing industry, Working Paper Series, Núcleo de Investigação em Políticas Económicas. Universidade do Minho, 2018

[11] Cheng, J., et al., Do consumers perceive differences among national brands, international private labels and local private labels? The case of Taiwan, In: Journal of Product \& Brand Management, 2007, 16, 6, 368-376

[12] Hsiao, S.-H., et al. How social media shapes the fashion industry: The spillover effects between private labels and national brands, In: Industrial Marketing Management, 2019

[13] Kupfer, D., Padrões de concorrência e competitividade, Conference: XX ANPEC 1992, At Campos do Jordão, 1992

[14] Mariotto, F., O conceito de competitividade da empresa: uma análise crítica, In: Revista de Administração de Empresas, 1991, 31, 2, 37-52

[15] Porter, M., What is Strategy?, In: Harvard Business Review, 1996, November-December

[16] Miranda, A., Vantagem competitiva em pequenos negócios: perspectivas à luz das capacidades dinâmicas - caso São Luís, Tese de Doutoramento, Istituto Universitário de Lisboa, 2017

[17] Teece, D., Pisano, G., Shuen, A., Dynamic capabilities and strategic management, In: Strategic Management Journal, 1997, 18, 7, 509-533

[18] Azeitão, J., Roberto, J., O planeamento estratégico e a gestão estratégica nas PME, Ordem dos Contabilistas Certificados, 2010, Março

[19] Porter, M., How competitive forces shape strategy, In: Harvard Business Review, 1979, March-April

[20] Moraes, C., Zilber, M., Estratégia e vantagem competitiva: um estudo do setor petroquímico brasileiro, In: Revista de Administração Mackenzie, 2004, 5, 1, 166-195

[21] Pinto, A., Henriques, C., Martinho, A.M., O impacto da inovação na rendibilidade empresarial: O caso do setor têxtil português, In: Revista Portuguesa e Brasileira de Gestão, 2014, Abr/Jun

[22] ITMF - International Textile Manufacturers Federation, International Production Cost Comparison 2018 (Revised edition), 2019

[23] Lee, Y.-J., Östberg, J., A case study of the Swedish fashion industry from the systems perspective of creativity, In: Journal of Global Fashion Marketing, 2013, 4, 2, 128-143

[24] Prunea, A., The competitiveness of textile industry, In: Annals of the University of Oradea. Fascicle of textiles, leatherwork, 2011

[25] Bontoux, L., Boucher, P., Scapolo, F., Textiles and Clothing Manufacturing: Vision for 2025 and Actions Needed, Joint Research Centre (JRC), European Commission's, 2017

[26] ATP - Associação Têxtil e Vestuário de Portugal, Fashion From Portugal. Yearbook. Textile and Clothing Industry Statistics: World, Europe and Portugal, Vila Nova de Famalicão: ATP, 2017

[27] Jang, J., et al., A Study of a Social Content Model for Sustainable Development in the Fast Fashion Industry, In: Journal of Global Fashion Marketing, 2012, 3, 2, 61-69

[28] Kratz, L., O processo criativo para o designer de moda, In: Estudos em Design, Revista (online), Rio de Janeiro, 2016, 24, 1, 169-196 
[29] Preiholt, H., From Collective Selection to Individual Style: A Symbolic Transfer in Fashion, In: Journal of Global Fashion Marketing, 2012, 3, 1

[30] Rossi, A., Harger, P., Influenciadoras digitais: o marketing de moda em tempos atuais, In: NAMID/UFPB, 2017, XIII, 9, Available at: http://periodicos.ufpb.br/ojs2/index.php/tematica [Accessed on August 2020]

[31] Lima, J., Os Empresários da Indústria Têxtil do Vale do Ave, Edições Afrontamento, 2018

[32] AICEP, Portugal Global - Indústria Têxtil e de Vestuário uma Referência a Nível Mundial, 2018, 113, Available at: http://portugalglobal.pt/PT/Paginas/Index.aspx [Accessed on August 2020]

[33] Sauders, M., Lewis, P., Thornhill, A., Research Methods for Business Students, 5th Edition. London: Finantial Times Prentice-Hall, 2009

[34] Larsson, R., Case Survey Methodology: Quantitative Analysis of Patterns Across Case Studies, In: The Academy of Management Journal, 1993, 36, 6, 1515-1546, https://doi.org/10.2307/256820

[35] Robson, C., Real world research: a resource for social scientists and practitiorer-researchers, 2nd Edition. Oxford: Blackwell Publishers Inc., 2002

[36] Yin, R.K., Case Study Research: Design and Method, 4th Edition. London: Sage Publications, 2009

[37] Gaskell, G., Pesquisa Qualitativa com texto, imagem e som - um Manual Prático, $7^{\text {a }}$ Edição. Petropólis, RJ: Vozes, 2008

\section{Authors:}

\section{GRAÇA GUEDES, PAULO VAZ}

2C2T - Centre of Textile Science and Technology, University of Minho, Campus de Azurém, 4804-533 Guimarães, Portugal

e-mail: paulovaz@aeportugal.pt

\section{Corresponding author:}

\section{GRAÇA GUEDES}

e-mail: mgg@det.uminho.pt 